(RESEARCH ARTICLE)

\title{
Comparative effect of chemical and organic fertilizers on primary metabolite contents of Ocimum bascilicum L. and Majorana hortensis Moench
}

\author{
Murthy Savitha M *, Tejaswini Arpana and Uthappa Reachal K. \\ Department of Botany, Mount Carmel College Autonomous, Bengaluru 560 052, India.
}

Publication history: Received on 19 September 2018; revised on 08 October 2018; accepted on 11 October 2018

Article DOI: https://doi.org/10.30574/gscbps.2018.5.1.0104

\begin{abstract}
Organic fertilizers are useful substitutes to inorganic fertilizers which improve the soil quality. In the present work, it was shown that organic fertilizers works better on primary metabolite contents of Ocimum basilicum and Marjorana hortensis than chemical fertilizers. Marjorana plant showed increased primary metabolite content compared to Ocimum plant under the treatment of organic fertilizers, but there was significant difference between the two plants indicating organic fertilizers were better. It concludes in general that applying organic fertilizers to the plants is an ecofriendly technique to improve the yield and quantity of the plants.
\end{abstract}

Keywords: Organic fertilizer; Morphology; Chemical fertilizer; Metabolite

\section{Introduction}

Medicinal and aromatic plants represent an important source of income in agricultural economy in many countries. Nature has gifted a very rich botanical wealth and a large number of diverse types of plants [1]. For about seventy years, people have been assured that poor quality soil is no longer an issue, as long as they rely on fertilizer products. Fertilizers are believed to infuse nutrients into soil, enabling all plants to prosper [2]. The heavy use of chemical fertilizers leads to adverse environmental, agricultural and health consequences. The use of biofertilizers is eco-friendly alternate sources to meet the nutrients requirements of the crop [3]. In general, biofertilizers application is a good tool to reduce the rate of chemical fertilizers, the cost of crop production and to allow for a better environment.

Soil will diminish gradually due to soil erosion, loss of nutrients, accumulation of salts and others toxic elements, water logging and unbalanced nutrients compensation. Organic fertilizers and chemical fertilizers are the alternative sources to meet the nutrients requirement of crop and to bridge the future gaps. To overcome the deficient in nutrient supply the best available option lies in the complimentary use of fertilizers.

Nutrient supplying capacity of soil declines steadily under continuous and intensive cropping system. The high increase in secondary and micro nutrient deficiencies and also unfavorable alterations in the physical and chemical properties of soil. Apart from the soil fertility and productivity issues, use of chemical fertilizers is also becoming more and more difficult for the farmers due to their high costs and scarcity during peak seasons $[4,5]$.

Composting is a biological process in which the organic wastes which are biodegradable can be converted into hygienic product and can be used as an organic fertilizer. The addition of municipal solid waste compost to agricultural soils has beneficial effects on crop development and yield [6].

\footnotetext{
${ }^{*}$ Corresponding author

E-mail address: jeejamurthy@gmail.com
} 
Organic matter improves water holding capacity of sandy soil and drainage in clay soil. The organic fertilizers are found positive contribution to soil fertility, resulting in an increase in crop yield without causing any environmental, water or soil pollution hazards. Nitrogen fixing and Phosphorous solubilizing bacteria play an important role in Nitrogen mobilization and Phosphorous solubilization for the benefit of plant growth. They are considered to be an important eco-friendly alternative source of plant nutrition. They have emerged as promising component of integrating nutrient supply system in agriculture. Organic fertilizers have attracted greater attraction particularly in developing countries including India as a substitute for costly fertilizers. Organic fertilizers can obviate the need of importation and all the same prove to be cost effective and compatible with ecology [7].

The present study was conducted to know the difference between Ocimum bascilicum and Majorana hortensis on primary metabolite content when supplemented with organic and chemical fertilizers.

\section{Material and methods}

\subsection{Source of the material}

Ocimum basilicum L. and Majorana hortensis Moench were procured from Lalbag Botanical Gardens, Bengaluru and GKVK, University of Agricultural Science, Bengaluru respectively. Organic fertilizers and chemical fertilizers were also collected from GKVK, University of Agricultural Science, Bengaluru. The organic fertilizers were prepared by decomposition of biodegradable organic matter like dried leaves, fruit and vegetable peel and cow dung, composed for about 3 months and the chemical fertilizer used were Specialty fertilizer- Poorna-19 (NPK in the ratio 19:19:19).

The plants were potted in the pots which had the sterilized soil. The treatments with organic and chemical fertilizers to the potted plants were given after 10 days of planting. The pots without the treatment served control. The primary metabolites were analyzed periodically after 30,60and 90 days after planting (DAP) using standard methods like total chlorophyll [8], total soluble proteins [9] and total free amino acids [10].

\subsection{Total chlorophyll}

$1 \mathrm{~g}$ each of fresh leaf samples of chemical fertilizer and organic fertilizer treated plants were finely ground with $20 \mathrm{ml}$ of $80 \%$ acetone. It was centrifuged at $5000 \mathrm{rpm}$ for 10 minutes and the supernatant was collected. The residue was again re extracted until the residue becomes colourless. Optical density was read in a spectrophotometer (Elico SL 171) at $645 \mathrm{~nm}$ and $663 \mathrm{~nm}$ against the solvent blank. The amount of chlorophyll present in the extract mg/chlorophyll /g tissue was calculated by using formula

Chlorophyll a g/tissue $=12.7\left(\mathrm{~A}_{663}\right)-2.69\left(\mathrm{~A}_{645}\right)$

Chlorophyll b g/tissue $=22.9\left(\mathrm{~A}_{645}\right)-4.68\left(\mathrm{~A}_{663}\right)$

Total chlorophyll g / tissue $=20.2\left(\mathrm{~A}_{645}\right)-8.02\left(\mathrm{~A}_{663}\right)$

\subsection{Total soluble proteins}

$100 \mathrm{mg}$ of leaf samples were homogenized separately in $10 \mathrm{ml}$ of distilled water under ice cold conditions. The homogenate was centrifuged at $3000 \mathrm{rpm}$ for 10 minutes and the supernatant was collected and $5 \mathrm{ml}$ of $10 \%$ TCA was added to it. The solution was re centrifuged and precipitate was collected and dissolved in $20 \mathrm{ml}$ of $1 \mathrm{~N} \mathrm{NaOH}$ and the protein solution was obtained. To $1 \mathrm{ml}$ of solution, $5 \mathrm{ml}$ of reagent $\mathrm{C}$ was added and incubated for 10 minutes at room temperature. Then $0.5 \mathrm{ml}$ of reagent $\mathrm{D}$ was added and incubated for 30 minutes. The optical density was read at 640 $\mathrm{nm}$. The amount of total proteins was determined using bovine serum albumen (BSA) as standard.

\subsection{Total free amino acids}

$100 \mathrm{mg}$ of leaf samples were extracted in $10 \mathrm{ml}$ of distilled water and the homogenate was centrifuged at $3000 \mathrm{rpm}$ for 10 minutes. $0.1 \mathrm{ml}$ of the supernatant was collected and added $1 \mathrm{ml}$ of ninhydrin solution. The solution was heated in a boiling water bath for 20 minutes. After cooling, $5 \mathrm{ml}$ of diluent solvent was added. After 15 minutes the purple colour intensity was read at $570 \mathrm{~nm}$. The amount of free amino acids was calculated by plotting a standard graph of glycine. 


\subsection{Statistical Analysis}

Data analysis was done by using SPSS software. The ANOVA test was used to determine significant $(\mathrm{P}>0.05)$ treatment effect and DMRT to determine significant difference between individual means [11].

\section{Results and discussion}

The quantitative estimations of the primary metabolite contents like chlorophyll, total carbohydrates, total proteins and total free amino acids in the treated plants were analyzed periodically after 30, 60 and 90 DAP intervals.

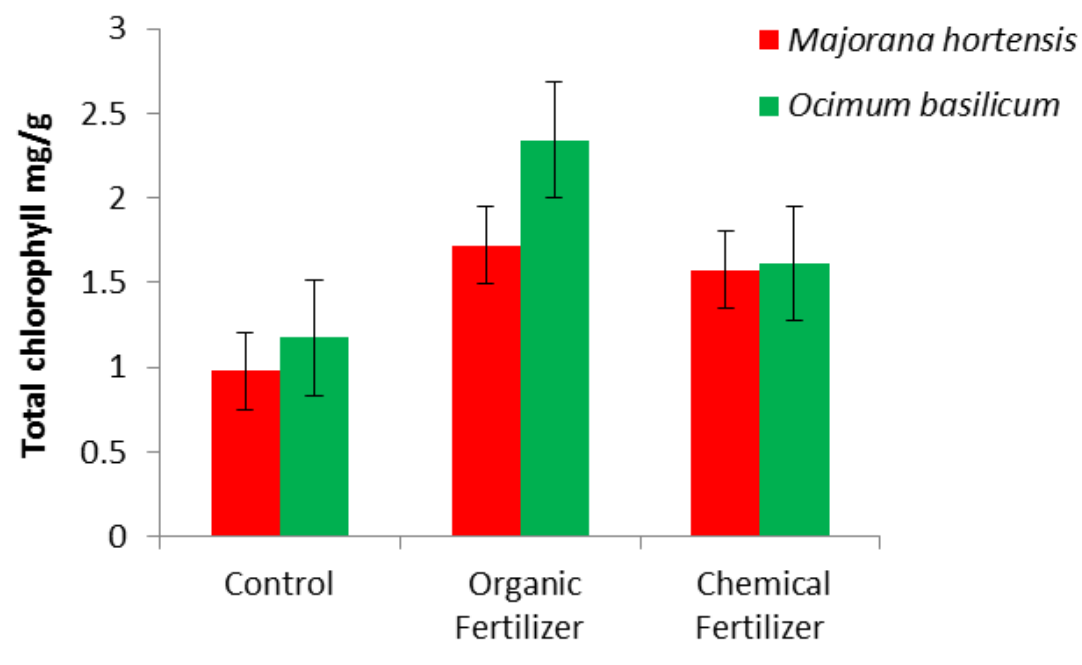

Figure 1 Effect of chemical and organic fertilizers on the total chlorophyll content

The results indicated that the total chlorophyll content at all intervals was increased drastically than the control. Organic fertilizers treated plants showed increased chlorophyll content compared to chemical fertilizer treated plants in both Ocimum and Majorana. Ocimum showed significant increased content compared to Majorana (Figure 1).

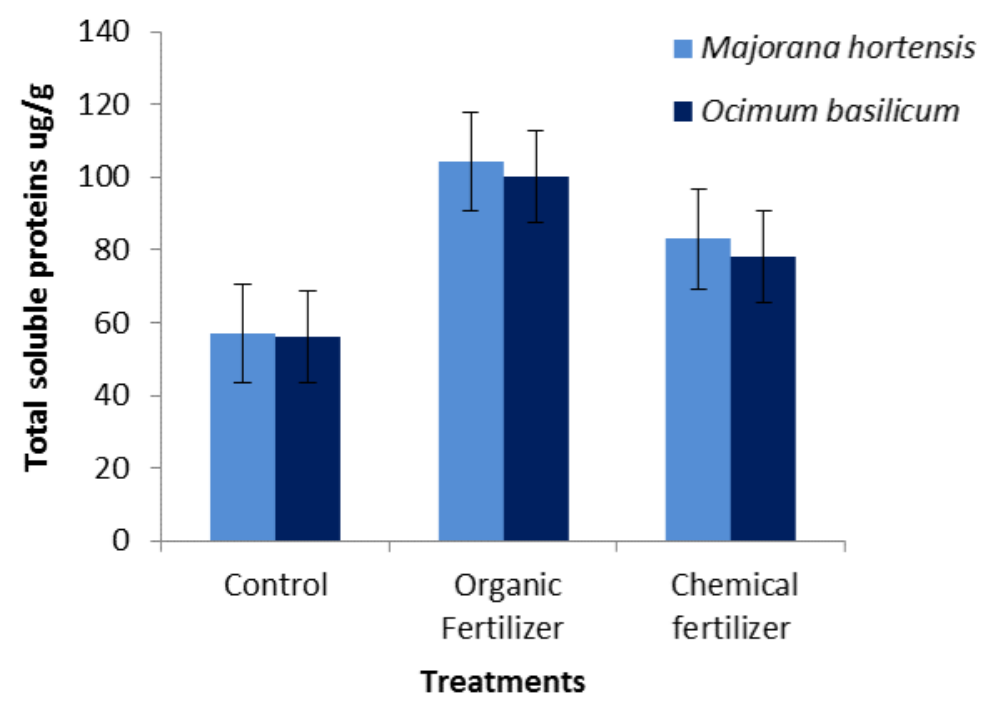

Figure 2 Effect of chemical and organic fertilizers on total soluble proteins

The organic fertilizers added to soil provides macronutrients and micro nutrients, which are assimilated and utilized for various metabolic activities to improve the synthesis of chlorophyll, required for their normal growth and developments. Accumulation of carbohydrate was high in plant treated with organic fertilizer due to high deposition of 
chlorophyll pigments. The present results were par with the findings of [3] in Stevia rebaudiana. The results were similar with the application of rabbit manure to Catharanthus roseus, there was significant increase in the chlorophyll content [1]. Similar results were observed in Tagetes [12] and on clove basil plants [13].

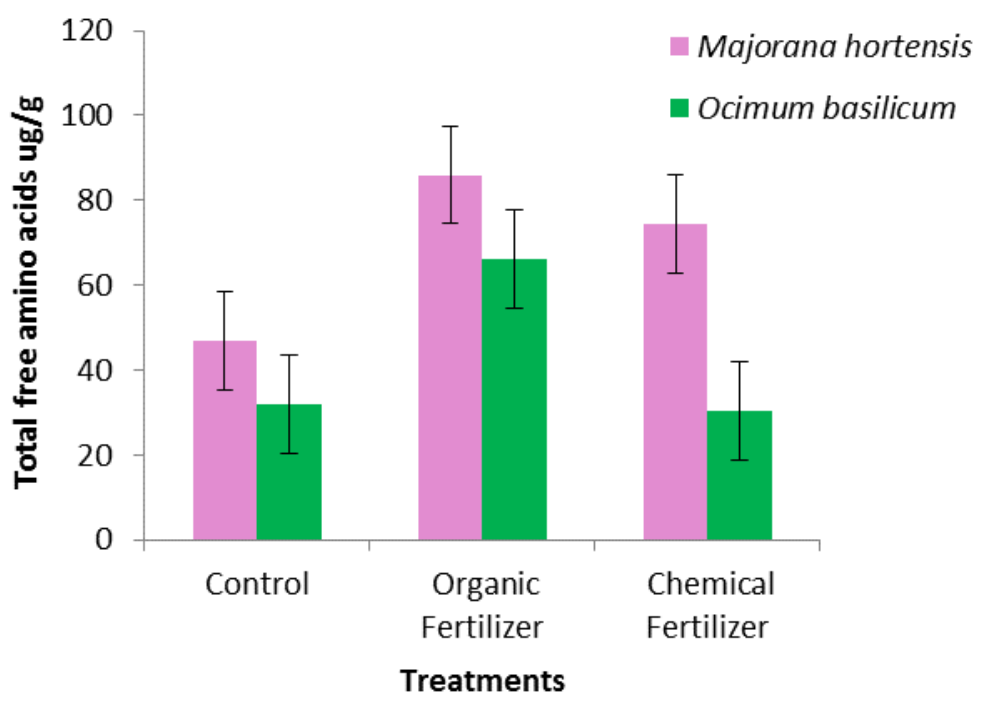

Figure 3 Effect of chemical and organic fertilizers on total free amino acids

Total soluble proteins and total free amino acids were increased in the organic fertilizer treated plants than chemical fertilizers. Ocimum showed increased protein content than Majorana plant (Figure 2 and 3). Protein synthesis turnover in growing plants is a basic component of metabolic regulation which provides a way for varying the enzymatic complement during the response to environmental conditions [14]. These results are in accordance with those obtained in pearl millet [15] and in maize [16]. The organic fertilizers added to soil provides macronutrients and micro nutrients, which are assimilated and utilized for various metabolic activities to improve the synthesis of amino acid, required for their normal growth and developments and also for the high accumulation of protein.

\section{Conclusion}

The use of organic matter such as animal manure, human waste, food wastes, sewage sludge and composts has long been recognized in agriculture as beneficial for plant growth and yield and the maintenance of soil fertility. The present research work also showed better yield compared with organic fertilizers compared to chemical fertilizers. It can be concluded that, the NPK fertilizers could be replaced by organic fertilizers to get quality crops.

\section{Compliance with ethical standards}

\section{Acknowledgments}

Authors are grateful to the Principal and management of Mount Carmel College, Autonomous, Bengaluru for the laboratory as well as financial support.

\section{Disclosure of conflict of interest}

All the authors have not declared any conflict of interest.

\section{References}

[1] Hassan EA. (2012). Effect of rabbit manure, VA mycorrhiza and Bacillus sirulans on growth, flowering and chemical constituents of periwinkle (Catharanthus roseus L.) plants. Australian Journal of basic and Applied Sciences, 6(13), $443-453$. 
[2] Shaheen MA, Abd ElWahab SM, El-Morsy FM and Ahmed ASS. (2013). Effect of organic and biofertilizers as a partial substitute for NPK mineral fertilizer on vegetative growth, leaf mineral content, yield and fruit quality of superior grapevine. Journal of Horticultural Science \& Ornamental Plants, 5(3), 151-159.

[3] Patil NN. (2010). Biofertilizers effect on growth, protein and carbohydrate content in Stevia rebaudiana Var Bertoni. Recent Research in Science and Technology, 2(10), 42 - 44.

[4] Peng XP and Letey J. (2000). Organic farming: Challenge of timing nitrogen availability to crop nitrogen requirements. Soil Science Society of America Journal, 64(1), 247 - 253.

[5] Chodhary AN, Farooq MS, Zeeshan M, Khan G, Chodhary TK and Abbas MS. (2017]. Crop yield and soil characteristics as affected by composts from different organic materials with spent wash. Advances in Crop Science and Technology, 5(3), 292.

[6] Gharib FA, Moussa LA and Massoud ON. (2008). Effect of compost and biofertilizers on growth, yield and essential oil content of sweet marjoram (Majorana hortensis) plant. International Journal of Agriculture and Biology, 10(4), $381-387$.

[7] Ibrahim MH, Jaafar HZE, Karimi E and Ghasemzadeh A. (2013). Impact of organic and inorganic fertilizers application on the phytochemical and antioxidant activity of Kacip Fatimah (Labisia pumila Benth.). Molecules, 18, 10973 - 10988.

[8] Arnon D. (1949). Copper enzymes in isolated chloroplasts and polyphenol oxidase in Beta vulgaris. Plant Physiology, 24, 1-15.

[9] Lowry OH, Rosebrough NJ, Lewis Farr A and Randall RJ. (1951) Protein measurement with the folin phenol reagent. Journal of Biological Chemistry, 193, 265 - 275.

[10] Moore KCP and Stein WH (1954) A modified ninhydrin reagent for the photometric determination of amino acids and related compounds. Journal of Biological Chemistry, 211, 907 - 913.

[11] Snedecor GW and Cochran WG. (1980). Statistical Methods. $7^{\text {th }}$ Ed., the Iowa State University Press. Ames., Iowa, USA, 593.

[12] Somida EG. (2002). Effect of organic manure, nitrogen and potassium fertilization on growth, flowering and chemical constituents of marigold plants (Tagetes minuta L.) Ph.D. Thesis Faculty of Agriculture, University of Egypt.

[13] Abdou MAH, Abdalla MYA, Hegaz, AA, Zeinab and Marzok SA. (2011). Physiological studies on clove basil plant. Journal of Plant Production, 2(11), 1451 - 1469.

[14] Huffaker RC and Peterson LW. (1974). Protein turnover in plants and possible means of its regulation. Annual Review of Plant Physiology, 25, 363-392.

[15] Tiwana MS, Chela GS, Thind IS, Puri KP and Kaur K. (1992). Effect of biofertilizers and nitrogen on the yield and quality of pearl millet folder. Annals of Biology, 8, 29-32.

[16] Chela GS, Tiwana MS, Thind IS, Puri KP and Kaur K. (1993). Effect of bacterial cultures and nitrogen fertility on the yield and quality of maize fodder (Zea mays L.). Annals of Biology, 9, 83 - 86.

\section{How to cite this article}

Murthy SM, Tejaswini A and Uthappa RK. (2018). Comparative effect of chemical and organic fertilizers on primary metabolite contents of Ocimum bascilicum L. and Majorana hortensis Moench. GSC Biological and Pharmaceutical Sciences, 5(1), 104-108. 